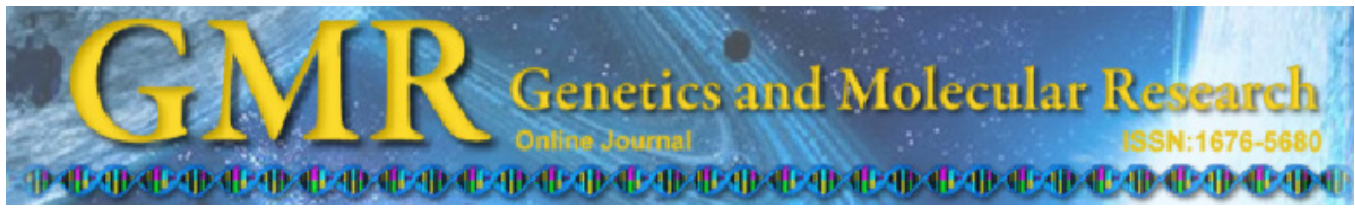

\title{
Antimutagenic and anticarcinogenic effects of wheat bran in vivo
}

\author{
J.R. Pesarini ${ }^{1,2,3}$, P.T. Zaninetti ${ }^{1}$, M.O. Mauro ${ }^{1,2,3}$, C.M. Carreira ${ }^{4}$, \\ J.B. Dichi ${ }^{4}$, L.R. Ribeiro ${ }^{2}$, M.S. Mantovani ${ }^{5}$ and R.J. Oliveira ${ }^{3,6,7}$ \\ ${ }^{1}$ Centro de Estudo em Nutrição e Genética Toxicológica, \\ Centro Universitário Filadélfia, Londrina, PR, Brasil \\ ${ }^{2}$ Programa de Pós-Graduação em Biologia Celular e Molecular, \\ Instituto de Biociências de Rio Claro, Universidade Estadual Paulista, \\ Rio Claro, SP, Brasil \\ ${ }^{3}$ Centro de Estudos em Células Tronco, Terapia Celular e Genética Toxicológica, \\ Núcleo de Hospital Universitário, Universidade Federal de Mato Grosso do Sul, \\ Campo Grande, MS, Brasil \\ ${ }^{4}$ Centro de Ciências da Saúde, Departamento de Ciências Farmacêuticas, \\ Universidade Estadual de Londrina, Londrina, PR, Brasil \\ ${ }^{5}$ Centro de Ciências Biológicas, Departamento de Biologia, \\ Universidade Estadual de Londrina, Londrina, PR, Brasil \\ ${ }^{6}$ Programa de Pós-Graduação em Saúde em Desenvolvimento na Região \\ Centro-Oeste, Faculdade de Medicina "Dr. Hélio Mandetta", \\ Universidade Federal de Mato Grosso do Sul, Campo Grande, MS, Brasil \\ ${ }^{7}$ Programa de Mestrado em Farmácia, Centro de Ciências Biológicas e da Saúde, \\ Universidade Federal de Mato Grosso do Sul, Campo Grande, MS, Brasil
}

Corresponding author: R.J. Oliveira

E-mail: rodrigo.oliveira@ufms.br

Genet. Mol. Res. 12 (2): 1646-1659 (2013)

Received August 14, 2012

Accepted December 18, 2012

Published May 14, 2013

DOI http://dx.doi.org/10.4238/2013.May.14.5

\begin{abstract}
Previous studies in rodents treated with the pro-carcinogen 1,2-dimethylhydrazine suggested that the consumption of wheat bran protected against DNA damage in the colon and rectum. Based on this information, we evaluated wheat bran as a functional food in the prevention and treatment of colon cancer. We used the aberrant crypt focus assay to evaluate the anticarcinogenic potential of wheat bran (Triticum aestivum
\end{abstract}


variety CD-104), the comet assay to evaluate its antigenotoxicity potential, and the micronucleus assay to evaluate its antimutagenic potential. The wheat bran gave good antimutagenic and anticarcinogenic responses; the DNA damage decreased from 90.30 to $26.37 \%$ and from 63.35 to $28.73 \%$, respectively. However, the wheat bran did not significantly reduce genotoxicity. Further tests will be necessary, including tests in human beings, before this functional food can be recommended as an adjunct in the prevention and treatment of colon cancer.

Key words: Chemoprevention; Functional food; Triticum aestivum; Wheat bran

\section{INTRODUCTION}

Cancer caused 7.6 million deaths worldwide in $2008,13 \%$ of the total 58 million deaths. More than $70 \%$ of all cancer deaths in 2008 occurred in low- and middle-income countries. According to data from the GLOBOCAN project, approximately 321,000 new cases of cancer occurred that year in Brazil, 21,768 of which were of colon and rectal cancer (also referred to as colorectal cancer), a rate similar to that observed in previous years (Ferlay et al., 2010). One of the main risk factors associated with the development of a tumor in the colon or rectum is a diet based on foods high in saturated and polyunsaturated fat, which is typical in Western industrialized countries and is becoming a major concern globally as this dietary preference spreads to low-income countries (Doll and Peto, 1981).

The treatment of colon cancer has progressed little during the last 30 years (Bailar and Smith, 1986), and new means of both treating this cancer and reducing its incidence are needed. However, methods for reduction should focus not only on reducing fat in the diet but also on food re-education (Greenwald and Cullen, 1985). Foremost in effective dietary changes is increasing the intake of grains such as wheat bran that contain high amounts of fiber and chemopreventive agents. These properties form the basis of the current study.

Considerable evidence has suggested that dietary fiber reduces the risk of colon cancer and other diseases such as diabetes and cardiovascular disease (Rimm et al., 1996). Several studies in animal models have found that dietary supplementation with grains and wheat bran helps to prevent colon cancer at both early (Jenab and Thompson, 1998) and late (Barbolt and Abraham, 1978) stages of tumor development. Studies have also shown a reduction of polyps (Jacobs et al., 2006) as well as an inhibition of cancer cell growth in the human colon (Sang et al., 2006).

The chemopreventive effect of whole-wheat flour has been attributed to its high levels of fiber and phytic acid [myo-inositol hexakis (dihydrogen-phosphate)] (Graf and Eaton, 1993). Whole-wheat flour and phytic acid protect against new biomarkers of colon cancer, reducing nuclear antigens and cell proliferation, for example (Jenab and Thompson, 1998). Studies of phytic acid have revealed preventive results in human beings. According to Tian and Song (2006), phytic acid is a potent inhibitor of cell proliferation in the carcinogenic HT-29 cell lineage from the colonic region, modulating the expression of cell cycle regulators.

In colon cancer, a well-established relationship exists among cell proliferation, differentiation, and apoptosis that is central to understanding the process of disease prevention. An increase or loss of control of cell proliferation along with DNA damage can lead to changes 
in the morphology of the colon and the formation of aberrant crypts, whereas apoptosis eliminates these damaged cells (Alabaster et al., 1995). From these findings, the present study aimed to evaluate the antigenotoxic, antimutagenic, and anticarcinogenic effects of wheat bran in response to damage caused by 1,2-dimethylhydrazine (DMH) in Swiss male mice.

\section{MATERIAL AND METHODS}

\section{Animals and maintenance conditions}

Male Swiss mice (Mus musculus; $\mathrm{N}=70 ; 10$ animals per group), with an average weight of $30 \mathrm{~g}$ and of reproductive age at the beginning of the adaptation period (7 days), were used for this study. The animals were housed in boxes made of propylene lined with white pine sawdust. They were fed a basal commercial ration (Sanex, Brazil) and given filtered water ad libitum. A 12-h photoperiod (12-h light, 12-h dark) was used, and the temperature and humidity were set at $22 \pm 2{ }^{\circ} \mathrm{C}$ and $55 \pm 10 \%$, respectively. The experiment was approved by the Committee of Ethics in Animal Experimentation at the State University of Londrina (CEEA No. 53/08; 91/2008).

\section{Chemical agents}

\section{DMH}

DMH at a dose of $30 \mathrm{mg} / \mathrm{kg}$ body weight (b.w.) was diluted at the time of use in an aqueous solution of ethylenediaminetetraacetic acid (EDTA; $0.37 \mathrm{mg} / \mathrm{mL}$ ) and administered to the animals intraperitoneally $(i p)$. Treatment was performed according to the protocol of Rodrigues et al. (2002). Briefly, 4 doses of DMH were administered in total, 2 doses each week for 2 weeks.

\section{Wheat bran}

The diet was supplemented with wheat grains ground and dried at a concentration of $100 \mathrm{~g} / \mathrm{kg}$ as specified in a previous study conducted in Centro de Estudos em Nutrição e Genética Toxicológica with other types of fiber (Ishii et al., 2011). This prepared food was offered daily to the animals ad libitum. The functional food was donated by De Marchi ${ }^{\circledR}$ Ltda., Brazil. The wheat (Triticum aestivum Linnaeus) variety CD-104 was grown at Cambuí Farm (Manoel Ribas, PR, Brazil) for the 2007/2007 harvest. The seed used in planting CD-104 was developed by COODETEC ${ }^{\circledR}$ Ltda., Brazil.

\section{Experimental design}

\section{Treatment groups}

The animals were treated for 12 weeks according to the protocol suggested by Bolognani et al. (2001) and described below. Group 1, the control group, received the standard commercial ration ad libitum throughout the 12 weeks. In the $3 \mathrm{rd}$ and 4 th weeks of experimen- 
tation, the animals received 4 doses of EDTA $(0.1 \mathrm{~mL} / 10 \mathrm{~g}$ b.w., ip $)$. After the last administration, samples of peripheral blood were collected by puncturing the tail vein for evaluation of genotoxicity, mutagenicity, antigenotoxicity, and antimutagenicity. Mutagenicity was evaluated with the micronucleus assay (MA) and was carried out 3 times, designated T1, T2, and $\mathrm{T} 3$, at 24,48 , and $72 \mathrm{~h}$, respectively, after the last administration of the medium. Genotoxicity was evaluated with the comet assay (CA) only at $\mathrm{T} 1$.

Group 2, the DMH group, received the experimental treatments described for group 1, but DMH (30 mg/kg b.w., ip) was administered instead of EDTA. Group 3, the wheat bran group, received commercial ration supplemented with $100 \mathrm{~g} / \mathrm{kg}$ wheat bran ad libitum for 12 weeks. During the 3rd and 4th weeks of experimentation, the animals were treated as those in group 1, and blood samples were obtained as described previously.

Group 4, the pre-treatment group, received a commercial ration supplemented with $10 \%$ wheat bran during the first 2 weeks of experimentation. From the 3rd to the 12th week, the animals received commercial ration. Treatment with DMH $(30 \mathrm{mg} / \mathrm{kg}$ b.w., ip $)$ occurred in the 3rd and 4th weeks as described above, and the blood collection was carried out as described for group 1.

Group 5, the simultaneous group, received DMH (30 mg/kg b.w., ip) during the $3 \mathrm{rd}$ and 4th weeks of experimentation, and, during these weeks, commercial ration supplemented with $100 \mathrm{~g} / \mathrm{kg}$ wheat bran was also provided ad libitum. In all other weeks, the animals received commercial ration. Blood collection took place as described for group 1.

Group 6, the post-treatment group, received DMH (30 mg/kg b.w., ip) during the $3 \mathrm{rd}$ and 4 th weeks of treatment. In the 8 weeks that followed, they were offered commercial ration supplemented with $100 \mathrm{~g} / \mathrm{kg}$ wheat bran ad libitum. Blood collection was carried out as described for group 1.

Group 7, the pre + continuous group, received commercial ration supplemented with $100 \mathrm{~g} / \mathrm{kg}$ wheat bran during the 12 -week period. During the $3 \mathrm{rd}$ and 4th weeks, they were treated with DMH (30 mg/kg b.w., ip $)$. Blood collection was carried out as described for group 1. After the 12th week of experimentation, all animals were killed via cervical dislocation for intestine collection to test for aberrant crypt foci (ACF).

\section{$M \boldsymbol{A}$}

The MA used in this experiment was originally described by Hayashi et al. (1990) with modifications by Oliveira et al. (2009). The slides were warmed to $70^{\circ} \mathrm{C}$ and covered with $20 \mu \mathrm{L}$ acridine orange in an aqueous solution $(1.0 \mathrm{mg} / \mathrm{mL})$. After slide preparation, a drop of peripheral blood was deposited on the slide and covered with a coverslip. Analysis was performed with a fluorescence microscope (Bioval, Brazil) at 40X magnification, with a 420- to 490-nm excitation filter and a 520-nm barrier filter. Approximately 2000 cells were analyzed per animal, and the data were obtained through analysis of variance (ANOVA) or the Tukey test $(\mathrm{P}<0.05)$.

\section{$C A$}

Alkaline CA was performed under indirect light (Tice et al., 2000). Briefly, $20 \mu \mathrm{L}$ blood cell suspension was embedded in $120 \mu \mathrm{L} 0.5 \%$ low-melting point agarose and lay- 
ered on a precoated slide with a thin layer of normal-melting point agarose. The slide was covered with a glass coverslip and cooled to $4{ }^{\circ} \mathrm{C}$ for $20 \mathrm{~min}$. The slides were immersed in lysis solution for $1 \mathrm{~h}$ and then transferred to an electrophoresis buffer for $20 \mathrm{~min}$ for denaturation and electrophoresed in buffer with a pH of $>13.0$ at $4{ }^{\circ} \mathrm{C}$ for $20 \mathrm{~min}$. The slides were then neutralized, air-dried, and fixed in absolute ethanol for $10 \mathrm{~min}$. The slides were stained with $100 \mu \mathrm{L}$ ethidium bromide $\left(20 \times 10^{-3} \mathrm{mg} / \mathrm{mL}\right)$ and evaluated using a fluorescence microscope (Bioval, Brazil) at 40X with an excitation filter of 420-490 $\mathrm{nm}$ and a barrier filter of $520 \mathrm{~nm}$.

Three independent repetitions were performed, and 100 cells were scored per treatment, classifying the comets as follows: class 0 , cells without comet tails; class 1 , cells with tails less than the diameter of the nucleus; class 2, cells with tails 1-2 times the diameter of the nucleus; and class 3, cells with tails greater than 2 times the diameter of the nucleus. Apoptotic cells that showed a completely fragmented nuclei were not counted (Kobayashi et al., 1995). The total score was calculated by summing the values after multiplication of the total cells observed in each class of lesion by the number of the class. Statistical analysis was performed using ANOVA followed by the Tukey-Kramer test $(\mathrm{P}<0.05)$.

\section{ACF assay}

After the animals were killed, laparotomy was performed to remove the colon, which was opened along the insert mesenteric edge and stored in $10 \%$ formalin buffer solution. For analyses, each segment of the colon was stained with 5\% methylene blue solution for $10 \mathrm{~min}$ and placed on a slide with the mucosa facing up to be analyzed under a light microscope (DBG, Brazil) at 10X magnification.

The identification of ACFs was based on the criteria of Bird (1987). For statistical data analysis, the total number of ACFs and aberrant crypts by focus and the relationship between crypt/focus in the various groups were compared. The statistical analysis was performed using ANOVA or the Tukey test $(\mathrm{P}<0.05)$.

\section{Calculation of damage reduction percentage (DR\%)}

The DMH DR\% related to wheat bran supplementation was calculated as follows: [DMH group mean - the mean of an associated group (groups 4, 5, 6, and 7)] / (DMH group mean - control group mean). The result was multiplied by 100 to obtain the percentage of reduction. This procedure was performed to evaluate the DR\% in CA, MA, and ACF assay.

\section{RESULTS}

The initial weights, final weights, and weight gains of mice during the experimental period are shown in Table 1. Statistical analysis indicated that the animals had similar weights at the beginning of the experiment, varying from $29.80 \pm 2.57$ to $35.20 \pm 1.04 \mathrm{~g}$. We found that the lowest final weight was observed in the group that received wheat bran supplementation and was not treated with DMH (wheat bran group, $37.40 \pm 0.84 \mathrm{~g}$ ). The groups treated with DMH with or without wheat bran supplementation had the highest weights, 
which varied from $42.20 \pm 1.34$ to $44.80 \pm 1.20 \mathrm{~g}$. In terms of weight gain, the group with the highest increase was that treated with $\mathrm{DMH}$ and supplemented with a commercial ration (DMH group, $44.60 \pm 1.86 \mathrm{~g}$ ), followed by the groups that received DMH associated with dietary supplementation of wheat bran.

\begin{tabular}{|c|c|c|c|}
\hline Experimental group & Initial weight (g) & Final weight (g) & Weight gain (g) \\
\hline Control & $31.20 \pm 0.67^{\mathrm{a}}$ & $40.80 \pm 1.30^{\mathrm{a}, \mathrm{b}}$ & $9.60 \pm 1.25^{\mathrm{a}, \mathrm{c}}$ \\
\hline DMH & $29.80 \pm 2.57^{\mathrm{a}}$ & $44.60 \pm 1.86^{\mathrm{b}}$ & $14.80 \pm 1.20^{\circ}$ \\
\hline Wheat bran & $30.00 \pm 1.03^{\mathrm{a}}$ & $37.40 \pm 0.84^{\mathrm{a}}$ & $7.40 \pm 0.67^{\mathrm{a}}$ \\
\hline Pre-treatment & $35.20 \pm 1.04^{a}$ & $44.20 \pm 1.05^{\mathrm{b}}$ & $9.00 \pm 0.80^{\mathrm{a}, \mathrm{b}}$ \\
\hline Simultaneous & $33.80 \pm 0.86^{\mathrm{a}}$ & $44.80 \pm 1.20^{\mathrm{b}}$ & $11.00 \pm 0.95^{\mathrm{a}, \mathrm{c}}$ \\
\hline Post-treatment & $30.66 \pm 2.16^{\mathrm{a}}$ & $43.33 \pm 1.00^{\mathrm{b}}$ & $12.66 \pm 1.88^{b, c}$ \\
\hline Pre + continuous & $33.40 \pm 1.26^{\mathrm{a}}$ & $42.20 \pm 1.34^{\mathrm{a}, \mathrm{b}}$ & $8.80 \pm 0.61^{\mathrm{a}, \mathrm{b}}$ \\
\hline \multicolumn{4}{|c|}{$\begin{array}{l}\mathrm{SE}=\text { standard error of the average. Experimental groups: Control - Group } 1 \text { - negative control - EDTA } 0.1 \mathrm{~mL} / 10 \\
\mathrm{~g} \text { b.w., ip, } 4 \text { doses; commercial ration for } 12 \text { weeks. DMH - Group } 2 \text { - positive control - } 1 \text {,2-dimethylhydrazine } \\
\text { (DMH) } 30 \mathrm{mg} / \mathrm{kg} \text { b.w., ip, } 4 \text { doses; commercial ration for } 12 \text { weeks. Wheat bran - Group } 3 \text { - EDTA } 0.1 \mathrm{~mL} / 10 \\
\mathrm{~g} \text { b.w., ip, } 4 \mathrm{doses} \text {; commercial ration supplemented with } 100 \mathrm{~g} / \mathrm{kg} \text { wheat bran for } 12 \text { weeks. Pre-treatment - } \\
\text { Group } 4 \text { - DMH } 30 \mathrm{mg} / \mathrm{kg} \text { b.w., ip, } 4 \text { doses; commercial ration supplemented with } 100 \mathrm{~g} / \mathrm{kg} \text { wheat bran during the } \\
\text { first } 2 \text { weeks. Simultaneous - Group } 5 \text { - DMH } 30 \mathrm{mg} / \mathrm{kg} \text { b.w., ip, } 4 \text { doses; they also received commercial ration } \\
\text { supplemented with } 100 \mathrm{~g} / \mathrm{kg} \text { wheat bran during the weeks of DMH administration. Post-treatment - Group } 6 \text { - DMH } \\
30 \mathrm{mg} / \mathrm{kg} \text { b.w., ip, } 4 \text { doses; commercial ration supplemented with } 100 \mathrm{~g} / \mathrm{kg} \text { wheat bran for the last } 8 \text { weeks; Pre }+ \\
\text { continuous - Group } 7 \text { - DMH } 30 \mathrm{mg} / \mathrm{kg} \text { b.w., ip, } 4 \text { doses; commercial ration supplemented with } 100 \mathrm{~g} / \mathrm{kg} \text { wheat bran } \\
\text { for } 12 \text { weeks. Different letters indicate statistically significant differences }(\mathrm{P}<0.05 \text {; ANOVA } / \text { Tukey test). }\end{array}$} \\
\hline
\end{tabular}

Table 2 presents the total and relative organ weights of the animals. Statistical analysis showed no differences between the absolute weights of the heart in any of the experimental groups. The liver, kidneys, and lungs displayed statistically significant differences; the highest values were seen in the groups treated with $\mathrm{DMH}$, and the lowest values occurred in the wheat and control groups. When the relative organ weights were analyzed, a significant difference was noticed in lung weight, with the highest value in the post-treatment group $(0.0074 \pm 0.0004 \mathrm{~g})$ and the lowest in the pre + continuous group $(0.0056 \pm 0.0002 \mathrm{~g})$. No statistically significant differences were observed among the relative weights of other organs.

Table 3 shows the frequency of damaged cells, distribution between classes of damage, and scores from the CA. The CA showed that the wheat bran group and the control group averaged $0.30 \pm 0.2134$ and $0.40 \pm 0.2211$ damaged cells, respectively. These values were the same as those observed in the scoring of damaged cells and were not significant for these parameters. In the DMH group, the average number of damaged cells was $99.60 \pm 0.2211$, and the score was $249.90 \pm 11.5100$. Wheat bran showed little positive antigenotoxic activity. Only the analysis of the post-treatment group showed antigenotoxic activity. The average value of damaged cells ranged from $17.90 \pm 3.6100$ to $99.60 \pm 0.3055$ in the post-treatment group and simultaneous group, respectively. Analysis of the score indicated that the best protection was also observed in the post-treatment group. The highest average value was seen for the simultaneous group, which was even higher than the score for the DMH group. 
J.R. Pesarini et al.

1652

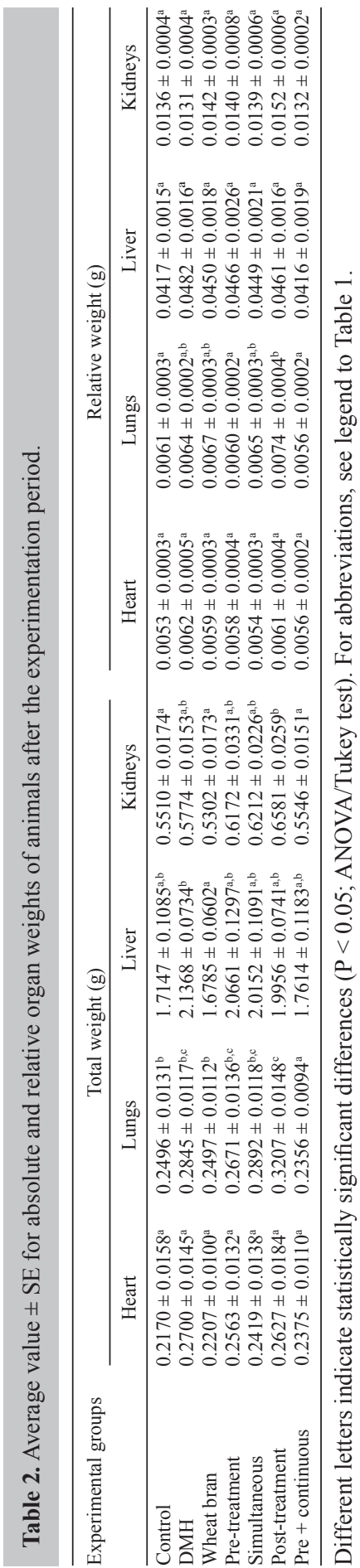

Genetics and Molecular Research 12 (2): 1646-1659 (2013) 


\begin{tabular}{|c|c|c|c|c|c|c|c|}
\hline \multirow[t]{2}{*}{ Treatments } & \multirow[t]{2}{*}{ Lesioned cells } & \multicolumn{4}{|c|}{ Damage classes } & \multirow[t]{2}{*}{ Score } & \multirow[t]{2}{*}{$\mathrm{DR} \%$} \\
\hline & & 0 & 1 & 2 & 3 & & \\
\hline \multicolumn{8}{|l|}{ Genotoxicity } \\
\hline Control & $0.40 \pm 0.2211^{\mathrm{a}}$ & $99.60 \pm 0.2211^{\mathrm{a}}$ & $0.40 \pm 0.2211^{\mathrm{a}, \mathrm{b}}$ & $0.00 \pm 0.00^{\mathrm{a}}$ & $0.00 \pm 0.00^{\mathrm{a}}$ & $0.40 \pm 0.2211^{\mathrm{a}}$ & - \\
\hline $\mathrm{DMH}$ & $99.60 \pm 0.2211^{\mathrm{b}}$ & $0.40 \pm 0.2211^{\mathrm{b}}$ & $15.10 \pm 4.067^{\mathrm{b}, \mathrm{c}}$ & $18.70 \pm 5.473^{\mathrm{b}}$ & $65.80 \pm 7.952^{\mathrm{c}}$ & $249.90 \pm 11.5100^{d}$ & - \\
\hline Wheat bran & $0.30 \pm 0.2134^{\mathrm{a}}$ & $99.70 \pm 0.2134^{\mathrm{a}}$ & $0.30 \pm 0.2134^{\mathrm{a}}$ & $0.00 \pm 0.00^{\mathrm{a}}$ & $0.00 \pm 0.00^{\mathrm{a}}$ & $0.30 \pm 0.2134^{\mathrm{a}}$ & - \\
\hline \multicolumn{8}{|l|}{ Antigenotoxicity } \\
\hline Pre-treatment & $39.20 \pm 6.8030^{\mathrm{a}, \mathrm{b}}$ & $60.80 \pm 6.8030^{\mathrm{a}, \mathrm{b}}$ & $27.70 \pm 6.7640^{c}$ & $9.70 \pm 4.487^{\mathrm{a}, \mathrm{b}}$ & $1.80 \pm 0.9286^{\mathrm{a}}$ & $52.50 \pm 9.8050^{\mathrm{b}}$ & 60.88 \\
\hline Simultaneous & $99.60 \pm 0.3055^{\mathrm{b}}$ & $0.40 \pm 0.3055^{\mathrm{b}}$ & $1.80 \pm 0.8919^{\mathrm{a}, \mathrm{b}}$ & $9.20 \pm 2.804^{\mathrm{a}, \mathrm{b}}$ & $88.60 \pm 2.860^{\mathrm{b}}$ & $286.00 \pm 3.5180^{\mathrm{d}}$ & 0 \\
\hline Post-treatment & $17.90 \pm 3.6100^{\mathrm{a}, \mathrm{c}}$ & $82.10 \pm 3.6100^{\mathrm{a}, \mathrm{c}}$ & $10.30 \pm 2.5480^{\mathrm{a}, \mathrm{b}, \mathrm{c}}$ & $4.30 \pm 1.499^{\mathrm{a}, \mathrm{b}}$ & $3.30 \pm 1.972^{\mathrm{a}}$ & $28.80 \pm 7.9260^{\mathrm{a}, \mathrm{b}}$ & 82.35 \\
\hline Pre + continuous & $63.40 \pm 5.6080^{\mathrm{b}, \mathrm{c}}$ & $36.60 \pm 5.6080^{\mathrm{b}, \mathrm{c}}$ & $34.30 \pm 6.6200^{c}$ & $14.40 \pm 3.267^{\mathrm{b}}$ & $14.70 \pm 7.374^{\mathrm{a}}$ & $107.20 \pm 16.3730^{c}$ & 36.49 \\
\hline
\end{tabular}

The MA performed on mouse peripheral blood (Table 4) showed that the control group had absolute micronucleus frequencies of 23, 25, and 21, and the wheat bran group had frequencies of 23,19 , and 24 at $\mathrm{T} 1, \mathrm{~T} 2$, and $\mathrm{T} 3$, respectively. These values were statistically the same at all times when mutagenic activity for this grain was discarded. The average values of micronucleus frequency in the control group were similar at the 3 times of analysis and ranged from $2.10 \pm 0.23$ to $2.50 \pm 0.27$. These values were similar to those observed for the wheat bran group, which ranged from $1.90 \pm 0.28$ to $2.40 \pm 0.27$. However, the DMH group showed a high frequency of micronuclei $(282,144$, and 112 for T1, T2, and T3, respectively). In a general analysis of antimutagenicity, the absolute and medium values of micronucleus frequency indicated that at $\mathrm{T} 1$, the lowest frequencies were found in the simultaneous group and the highest frequencies occurred in the post-treatment group. This inference can also be made for T2. However, at T3, the lowest value was found in the pre-treatment group and the highest in the post-treatment group. When analyzing the DR\%, we observed that for T1 and $\mathrm{T} 2$, the simultaneous group displayed the best results, and the DR\% were 90.30 and $79.00 \%$, respectively. Yet at T3, the pre-treatment group showed the highest DR\% (89.01\%). At all times, the post-treatment group had the worst results, with DR\% of $60.20,44.50$, and $26.37 \%$ for $\mathrm{T} 1, \mathrm{~T} 2$, and $\mathrm{T} 3$, respectively.

The ACF assay (Table 5) results showed that the animals in the control and wheat bran groups had no lesions in the colorectal region, which demonstrates the absence of a possible carcinogenic effect of wheat bran. For the DMH group, the absolute value was 644 crypts, confirming the carcinogenic potential of this substance. When analyzing the anticarcinogenic properties of wheat bran in the pre-treatment, simultaneous, post-treatment, and pre + continuous groups, we observed DR $\%$ of $58.23,63.35,56.52$, and $28.73 \%$, respectively. The average ACF values for these anticarcinogens varied from $23.60 \pm 2.53$ to $45.90 \pm 2.70$, and statistical analysis indicated chemopreventive activity in all of these groups compared with activity in the DMH group. In relation to the total number of crypts, we verified that all anticarcinogenic groups differed statistically from the DMH group and that the total aberrant crypts varied from $34.40 \pm 4.44$ to $70.70 \pm 4.44$. For both the total ACFs and the total crypts, we verified that the group with the lowest and the highest averages were the simultaneous and pre + continuous groups, respectively. The highest value for crypt focus was found in the post-treatment group (1.92). 
Table 4. Total frequency, average values $\pm \mathrm{SE}$, and $\mathrm{DR} \%$ related to mutagenicity and antimutagenicity in the peripheral blood of mice when evaluating the micronucleus assay.

\begin{tabular}{|c|c|c|c|c|c|c|c|c|c|}
\hline \multirow[t]{2}{*}{ Experimental group } & \multicolumn{3}{|c|}{ Frequency of MN } & \multicolumn{3}{|c|}{ Average values $\pm \mathrm{SE}$} & \multicolumn{3}{|c|}{$\mathrm{DR} \%$} \\
\hline & $\mathrm{T} 1$ & $\mathrm{~T} 2$ & $\mathrm{~T} 3$ & $\mathrm{~T} 1$ & $\mathrm{~T} 2$ & $\mathrm{~T} 3$ & $\mathrm{~T} 1$ & $\mathrm{~T} 2$ & $\mathrm{~T} 3$ \\
\hline \multicolumn{10}{|l|}{ Mutagenicity } \\
\hline Control & 23 & 25 & 21 & $2.30 \pm 0.30^{\mathrm{a}}$ & $2.50 \pm 0.27^{\mathrm{a}}$ & $2.10 \pm 0.23^{\mathrm{a}}$ & - & - & - \\
\hline $\mathrm{DMH}$ & 282 & 144 & 112 & $28.20 \pm 0.75^{\mathrm{d}}$ & $14.40 \pm 0.52^{\mathrm{e}}$ & $11.20 \pm 0.55^{\mathrm{d}}$ & - & - & - \\
\hline Wheat bran & 23 & 19 & 24 & $2.30 \pm 0.42^{\mathrm{a}}$ & $1.90 \pm 0.28^{\mathrm{a}}$ & $2.40 \pm 0.27^{\mathrm{a}}$ & - & - & - \\
\hline \multicolumn{10}{|l|}{ Antimutagenicity } \\
\hline Pre-treatment & 51 & 62 & 31 & $5.10 \pm 0.31^{\mathrm{a}, \mathrm{b}}$ & $6.20 \pm 0.41^{\mathrm{b}}$ & $3.10 \pm 0.43^{\mathrm{a}}$ & 89.20 & 68.90 & 89.01 \\
\hline Simultaneous & 48 & 50 & 85 & $4.80 \pm 0.48^{\mathrm{a}, \mathrm{b}}$ & $5.00 \pm 0.63^{\mathrm{b}}$ & $8.50 \pm 0.52^{c}$ & 90.30 & 79.00 & 29.67 \\
\hline Post-treatment & 126 & 91 & 88 & $14.00 \pm 1.47^{\circ}$ & $10.11 \pm 0.75^{\mathrm{d}}$ & $9.77 \pm 0.46^{\mathrm{c}, \mathrm{d}}$ & 60.20 & 44.50 & 26.37 \\
\hline Pre + continuous & 69 & 59 & 56 & $6.90 \pm 0.31^{\mathrm{b}}$ & $5.90 \pm 0.53^{\mathrm{c}}$ & $5.60 \pm 0.37^{b}$ & 82.20 & 71.40 & 61.50 \\
\hline
\end{tabular}

$\mathrm{DR} \%=$ percentage of damage reduction; $\mathrm{MN}=$ micronucleus. Different letters indicate statistically significant differences $(\mathrm{P}<0.05 ;$ ANOVA/Tukey test). For other abbreviations, see legend to Table 1 .

Table 5. Number, distribution, and $\mathrm{DR} \%$ of $\mathrm{ACF}$ on colon of mice.

\begin{tabular}{|c|c|c|c|c|c|c|c|c|c|c|c|}
\hline \multirow[t]{2}{*}{ Experimental group } & \multicolumn{3}{|c|}{ ACF total } & \multirow[t]{2}{*}{ AC total } & \multicolumn{5}{|c|}{$\mathrm{AV}$ of $\mathrm{AC} /$ foci } & \multirow[b]{2}{*}{$\begin{array}{c}6 \mathrm{AC} / \\
\text { foci }\end{array}$} & \multirow[t]{2}{*}{$\mathrm{AC} /$ focus ratio } \\
\hline & $\mathrm{AV}$ & $\mathrm{VA} \pm \mathrm{SE}$ & $\mathrm{DR} \%$ & & $\begin{array}{c}1 \mathrm{AC} / \\
\text { foci }\end{array}$ & $\begin{array}{c}2 \mathrm{AC} / \\
\text { foci }\end{array}$ & $\begin{array}{c}3 \mathrm{AC} / \\
\text { foci }\end{array}$ & $\begin{array}{c}4 \mathrm{AC} / \\
\text { foci }\end{array}$ & $\begin{array}{c}5 \mathrm{AC} / \\
\text { foci }\end{array}$ & & \\
\hline \multicolumn{12}{|l|}{ Carcinogenicity } \\
\hline Control & 0 & $0.00 \pm 0.00^{\mathrm{a}}$ & - & $0.00 \pm 0.00^{\mathrm{a}}$ & 0 & 0 & 0 & 0 & 0 & 0 & $0.00 \pm 0.00^{\mathrm{a}}$ \\
\hline $\mathrm{DMH}$ & 644 & $64.40 \pm 5.58^{d}$ & - & $97.10 \pm 8.72^{\mathrm{d}}$ & 414 & 164 & 44 & 15 & 5 & 2 & $1.51 \pm 0.04^{b}$ \\
\hline Wheat bran & 0 & $0.00 \pm 0.00^{\mathrm{a}}$ & - & $0.00 \pm 0.00^{\mathrm{a}}$ & 0 & 0 & 0 & 0 & 0 & 0 & $0.00 \pm 0.00^{\mathrm{a}}$ \\
\hline \multicolumn{12}{|l|}{ Anticarcinogenicity } \\
\hline Pre-treatment & 269 & $26.90 \pm 3.53^{b}$ & 58.23 & $42.80 \pm 6.91^{\mathrm{a}, \mathrm{b}}$ & 151 & 87 & 24 & 5 & 1 & 1 & $1.53 \pm 0.07^{b}$ \\
\hline Simultaneous & 236 & $23.60 \pm 2.53^{b}$ & 63.35 & $34.40 \pm 4.44^{\mathrm{a}, \mathrm{b}}$ & 143 & 81 & 9 & 3 & 0 & 0 & $1.42 \pm 0.05^{\mathrm{b}}$ \\
\hline Post-treatment & 252 & $28.00 \pm 3.70^{\mathrm{b}}$ & 56.52 & $54.77 \pm 9.03^{c}$ & 113 & 75 & 36 & 18 & 10 & 0 & $1.92 \pm 0.16^{\mathrm{c}}$ \\
\hline Pre + continuous & 459 & $45.90 \pm 2.70^{c}$ & 28.73 & $70.70 \pm 4.44^{b}$ & 271 & 140 & 38 & 8 & 2 & 0 & $1.54 \pm 0.06^{\mathrm{b}}$ \\
\hline
\end{tabular}

$\mathrm{DR} \%=$ percentage of damage reduction; $\mathrm{ACF}=$ aberrant crypt foci; $\mathrm{AC}=$ aberrant crypts; $\mathrm{AV}=$ absolute values; $\mathrm{VA}=$ average. Different letters indicate statistically significant differences $(\mathrm{P}<0.05 ;$ ANOVA/Tukey test). For other abbreviations, see legend to Table 1.

\section{DISCUSSION}

This study showed that dietary supplementation with ground wheat bran can contribute to the prevention of colon cancer and mutagenic damage but confers no effective antigenotoxic activity. Even so, this study and others have shown that wheat bran can be an important functional food that reduces biomarkers for colon cancer (Wilson et al., 1977; Watanabe et al., 1979).

The antimutagenic and anticarcinogenic properties of wheat bran may be due in part to the presence of the antioxidant phytic acid (Vucenik and Shamsuddin, 2003) and to its insoluble fiber characteristics (Cummings, 1993). The antioxidant activity of phytic acid can modulate mutagenesis via desmutagenic and bioantimutagenic activity. Insoluble fiber dilutes the carcinogenic agents in the intestines, and by increasing intestinal transit speed (Marlett, 1993), it efficiently removes these agents from the body. Colonic fermentation of wheat bran through the normal body flora may also provide protection by releasing phytic acid ( $\mathrm{Li}$ et al., 2011) and short-chain fatty acids such as butyric acid (Topping and Clifton, 2001). The conclusions mentioned above are corroborated by the results of this study.

The CA indicated that wheat bran promotes a low level of antigenotoxic activity. 
We observed slight damage prevention only in the post-treatment group. This effect may be due to the simultaneous presence of $\mathrm{DMH}$, which was being metabolized in the intestinal lumen (releasing the carcinogenic metabolite azoxymethane) and wheat bran, which was being administered in the diet. In the pre-treatment and simultaneous treatment regimens, this efficiency was not achieved because the ingestion of wheat bran had already stopped at the point at which azoxymethane was released in the intestine, and the amount of wheat bran inside the intestine at that point was lower than that observed in the post-treatment group. Regarding the pre + continuous group, antigenotoxic action similar to or better than that of the post-treatment group was expected. However, we did not observe the same effect, possibly because the intestinal flora of the mice was unable to ferment the fiber for so many consecutive days.

When the antimutagenic action of wheat bran was evaluated in various protocols, a chemopreventive activity was found for all tests except in the post-treatment group at T3. The analysis of the DR\% indicated no consistent relationship among all protocols. In the pretreatment group, a decrease at T2 was found, but an increase in the DR\% occurred at T3. For the simultaneous, post-treatment, and pre + continuous treatment protocols, a decrease in the DR\% occurred from $\mathrm{T} 1$ to $\mathrm{T} 3$.

The analysis of the various protocols may indicate that the antimutagenic effect occurred through desmutagenesis and bioantimutagenesis, which are the 2 basic types of DNAprotective effects (Kada, 1981). Desmutagenic substances are capable of blocking damage-inducing agents mainly by adsorbing them, and they largely act in the extracellular environment. Bioantimutagenic agents are capable of damage prevention or work at the level of DNA repair, acting within the cell (Kada and Shimoi, 1987). De Flora (1998) has also suggested that bioantimutagenic substances act as modulators of repair and DNA replication, stimulate the errorfree repair pathway in DNA damage, or inhibit the repair systems subject to error.

To clarify the modes of action of molecules or chemical compounds conferring antimutagenicity, we must use various treatment protocols (Flagg et al., 1995). We selected 3 protocols from those proposed in the literature: pre-treatment, simultaneous, and post-treatment. An alternative protocol of pre + continuous proposed by Ishii et al. (2011) was also used. This simple treatment protocol indicates desmutagenic or bioantimutagenic activity; the pretreatment protocol largely indicates bioantimutagenic activity, and the post-treatment protocol exclusively shows bioantimutagenic activity. Based on these findings, we concluded that wheat bran demonstrates activities of both types.

As previously mentioned, the simultaneous treatment protocol may identify 2 modes of action. Wheat bran antioxidant agents, such as phytic acid, may intercept carcinogenic azoxymethane, inhibiting it even before it can damage DNA. Another possibility is that wheat bran antioxidant agents modulate repair enzymes so that damage can be fixed more quickly and efficiently. Desmutagenic action is possible in 2 environments: mutagenic and antimutagenic agents may interact in the extracellular environment, preventing the mutagenic compound from entering the cell, or they could interact within the cell, inactivating mutagenic agents before they reach the DNA.

The pre-treatment protocol makes both modes of action possible. The process of desmutagenesis is likely to occur in the cytoplasm rather than outside the cell because after the cessation of wheat bran administration, antimutagenic agents (such as antioxidants) left in the cytoplasm would intercept azoxymethane. Previous ingestion of wheat bran may also modulate repair enzymes, triggering the process of bioantimutagenesis. 
In the post-treatment protocol, the damage had already occurred, and even though mutagenic damage was prevented at $\mathrm{T} 1$ and $\mathrm{T} 2$, the wheat bran had the capability to modulate DNA repair enzymes. These same inferences were made in studies by Roberfroid (1991), in which the authors evaluated the antimutagenic mode of action of inulin, a natural fiber-like wheat bran, in cultured cells.

In other study, Oliveira et al. (2009) describe an experiment in which they administered an antimutagenic agent before, during, and after the application of a mutagenic agent. Thus, the authors proposed an improvement in the efficiency of chemopreventive action. However, in our research, significant improvement in the antimutagenic action by this extended protocol of administration was absent.

Comparisons of genotoxicity and mutagenicity clearly show that wheat bran is more effective as an antimutagenic agent than as an antigenotoxic agent. However, it is important to note that the lesions measured by CA and MA are different. The DNA lesions assessed in the CA could have been repaired, whereas those evaluated by MA were no longer subject to correction. This fact may explain why higher damage levels were observed in the CA compared to those measured in the MA.

The antigenotoxic and antimutagenic actions discussed herein may be due in particular to the presence of phytic acid. Phytic acid, also known as inositol hexaphosphate or IP6 (Shamsuddin et al., 1997), has phosphate groups at positions 1, 2, and 3 (axial-equatorialaxial) and interacts specifically with iron, completely inhibiting its capability to catalyze the formation of radical hydroxyls. This characteristic makes phytic acid a powerful antioxidant (Vucenik and Shamsuddin, 2003). It is widely accepted that phytic acid, and consequently wheat bran, is an antioxidant.

Phytic acid interacts only with tumor cells and causes no damage to normal cells. Absorption is believed to occur rapidly through mechanisms likely involving pinocytosis or receptor-mediated endocytosis. After entering the cell, phytic acid is transported intracellularly and dephosphorylated in smaller phosphate groups that act as antioxidants (Vucenik and Shamsuddin, 2003). Thus, its antimutagenic action is classified as desmutagenesis. Our present findings support these inferences.

Our ACF assessment indicated no important differences in the DR\% among the simultaneous, post-treatment, and pre-treatment protocols. We found that the pre + continuous group had the lowest DR\%, which may be due to the inability of the intestinal flora of the mice to ferment the entire fiber intake. A study by Blaut (2002) indicated that a pre-biotic diet that is fermented in the intestines can influence intestinal microflora balance in a complex manner and change its quantitative and qualitative composition (microorganisms and bacterial species). The results of this study reinforce the assumption we inferred in our research, since the consumption of fiber for a long period could change the microflora balance, leading to the results observed for the pre + continuous group.

The general analysis of our results from the MA indicated that the wheat germ activity was not only desmutagenic but also bioantimutagenic. Evaluating crypt foci, we verified that despite preventing the occurrence of an average number of crypt foci, the worst ratio of ACFs occurred in the post-treatment group, in which only bioantimutagenic activity took place. This result suggested that pre-neoplastic lesions could become tumors, especially in this group. It further suggests that a desmutagenic activity associated with a bioantimutagenic activity can more efficiently prevent cancer. 
All of the above genetic and morphological changes are due to the administration of $\mathrm{DMH}$. In the liver, the hydrolysis of DMH generates methylazoxymethanol, which, in conjunction with $\beta$-glucuronic acid, is carried to the intestinal lumen where the bacterial enzyme $\beta$-glucuronidase releases the active metabolite of $\mathrm{DMH}$, azoxymethane (Lamont and O'Gorman, 1978). This metabolite triggers a mild inflammatory reaction and an increase in cellular proliferation in the colonic mucosa in rodents. When administered chronically, this drug leads to continuous cell proliferation and the mutation $\mathrm{GC} \rightarrow \mathrm{AT}$ in specific genes associated with colorectal cancer, such as $\beta$-catenin and K-ras (Krustovskikh and Turosov, 1994). Assays that analyze comets, micronuclei, and ACFs quantify 3 types of DNA damage induced by DMH: genomic lesions that can be repaired, mutations, and pre-malignant lesions.

Beyond its antioxidant activity, wheat bran may also be beneficial as a source of insoluble dietary fiber. According to Maes et al. (2004), the main non-starch polysaccharides present in wheat bran are arabinoxylans (36.5\%), cellulose (11\%), lignin (3-10\%), and uronic acids (3-6\%). The anaerobic fermentation of these polysaccharides, largely by bifidobacteria in the mouse intestine, produces the short-chain volatile fatty acids acetate, propionate, and, in particular, butyrate; butyrate can modulate the expression of apoptotic genes in inflammatory cells and is maintained at high levels for long periods throughout the intestinal lumen (Hollmann and Lindhauer, 2005). Considering these facts, the addition of wheat bran or grains to the diet is likely beneficial to intestinal health by preventing the development of neoplasms or preneoplasms owing to the increased rate of apoptosis caused by high levels of butyrate. The fermentation of fiber by bifidobacteria decreases fecal $\mathrm{pH}$, creating a bacterial environment favorable to the putrefactive bacteria that are responsible for the release of azoxymethane. Therefore, the level of beneficial bacteria in the intestinal lumen increases, and they produce little or no $\beta$-glucuronidase, thus decreasing the levels of damaging agents in the intestinal mucosa (Roberfroid, 2005). At the same time, the activity of fiber itself is important. Ferguson (1994) reported that dietary fiber has a high adsorption capacity, meaning that the fibers act as a physical barrier that leads to the elimination of certain chemical substances, such as DMH, that induce DNA damage.

Based on these results, we conclude that wheat bran, a functional food that is already part of the human diet, is a strong candidate for dietary supplementation in cancer prevention and as an adjuvant to chemotherapy treatment. However, these results must be validated in human beings.

\section{ACKNOWLEDGMENTS}

Research supported by Fundação Araucária: Support for Scientific and Technological Development of Paraná, Pro-Search Rectory of Centro Universitário Filadélfia, Londrina, PR, Brazil.

\section{REFERENCES}

Alabaster O, Tang Z, Frost A and Shivapurkar N (1995). Effect of beta-carotene and wheat bran fiber on colonic aberrant crypt and tumor formation in rats exposed to azoxymethane and high dietary fat. Carcinogenesis 16: 127-132.

Bailar JC III and Smith EM (1986). Progress against cancer? N. Engl. J. Med. 314: 1226-1232.

Barbolt TA and Abraham R (1978). The effect of bran on dimethylhydrazine-induced colon carcinogenesis in the rat. Proc. Soc. Exp. Biol. Med. 157: 656-659. 
Bird RP (1987). Observation and quantification of aberrant crypts in the murine colon treated with a colon carcinogen: preliminary findings. Cancer Lett. 37: 147-151.

Blaut M (2002). Relationship of prebiotics and food to intestinal microflora. Eur. J. Nutr. 41 (Suppl 1): I-11-I-16.

Bolognani F, Rumney CJ, Pool-Zobel BL and Rowland IR (2001). Effect of lactobacilli, bifidobacteria and inulin on the formation of aberrant crypt foci in rats. Eur. J. Nutr. 40: 293-300.

Cummings JH (1993). Handbook of Dietary Fiber in Human Nutrition. In: The Effect of Dietary Fiber on Fecal Weight and Composition (Spiller GA, ed.). CRC Press, Boca Raton, 263-349.

De Flora S (1998). Mechanisms of inhibitors of mutagenesis and carcinogenesis. Mutat. Res. 402: 151-158.

Doll R and Peto R (1981). The causes of cancer: quantitative estimates of avoidable risks of cancer in the United States today. J. Natl. Cancer Inst. 66: 1191-1308.

Ferguson LR (1994). Antimutagens as cancer chemopreventive agents in the diet. Mutat. Res. 307: 395-410.

Ferlay J, Shin HR, Bray F, Forman D, et al. (2010). GLOBOCAN v1.2 - Cancer Incidence and Mortality Worldwide, IARC CancerBase No. 10/2010. Available at [http://globocan.iarc.fr]. Accessed August 13, 2012.

Flagg EW, Coates RJ and Greenberg RS (1995). Epidemiologic studies of antioxidants and cancer in humans. J. Am. Coll. Nutr. 14: 419-427.

Graf E and Eaton JW (1993). Suppression of colonic cancer by dietary phytic acid. Nutr. Cancer 19: 11-19.

Greenwald P and Cullen JW (1985). The new emphasis in cancer control. J. Natl. Cancer Inst. 74: 543-551.

Hayashi M, Morita T, Kodama Y, Sofuni T, et al. (1990). The micronucleus assay with mouse peripheral blood reticulocytes using acridine orange-coated slides. Mutat. Res. 245: 245-249.

Hollmann J and Lindhauer MG (2005). Pilot-scale isolation of glucuronoarabinoxylans from wheat bran. Carbohydrate Polymers 59: 225-230.

Ishii PL, Prado CK, Mauro MO, Carreira CM, et al. (2011). Evaluation of Agaricus blazei in vivo for antigenotoxic, anticarcinogenic, phagocytic and immunomodulatory activities. Regul. Toxicol. Pharmacol. 59: 412-422.

Jacobs ET, Lanza E, Alberts DS, Hsu CH, et al. (2006). Fiber, sex, and colorectal adenoma: results of a pooled analysis. Am. J. Clin. Nutr. 83: 343-349.

Jenab M and Thompson LU (1998). The influence of phytic acid in wheat bran on early biomarkers of colon carcinogenesis. Carcinogenesis 19: 1087-1092.

Kada T (1981). Environmental desmutagens and antidesmutagens. Indian J. Biochem. Biophys. 18: 5-6.

Kada T and Shimoi K (1987). Desmutagens and bio-antimutagens - their modes of action. Bioessays 7: 113-116.

Kobayashi H, Sugiyama C, Morikawa Y, Hayashi M, et al. (1995). A comparison between manual microscopic analysis and computerized image analysis in the single cell gel electrophoresis assay. MMS Comm. 3: 103-115.

Krutovskikh VA and Turosov VS (1994). Pathology of Tumors in Laboratory Animals. In: Tumors of Intestines (Turosov VS and Mohr U, eds.). Yarc, Lyon, 195-211.

Lamont JT and O'gorman TA (1978). Experimental colon cancer. Gastroenterology 75: 1157-1169.

Li SC, Chen CM, Lin SH, Chiang W, et al. (2011). Effects of adlay bran and its ethanolic extract and residue on preneoplastic lesions of the colon in rats. J. Sci. Food Agric. 91: 547-552.

Maes C, Vangeneugden B and Delcoour JA (2004). Relative activity of two endoxylanases towards water-unextractable arabinoxylans in wheat bran. J. Cereal Sci. 39: 181-186.

Marlett JA (1993). Oat bran. In: Comparisons of Dietary Fiber and Selected Nutrient Compositions of Oat and Other Grain Fractions (Wood P, ed.). American Association of Cereal Chemists, St. Paul, 49-82.

Oliveira RJ, Baise E, Mauro MD, Pesarini JR, et al. (2009). Evaluation of chemopreventive activity of glutamine by the comet and the micronucleus assay in mice's peripheral blood. Environ. Toxicol. Pharmacol. 28: 120-124.

Rimm EB, Ascherio A, Giovannucci E, Spiegelman D, et al. (1996). Vegetable, fruit, and cereal fiber intake and risk of coronary heart disease among men. JAMA 275: 447-451.

Roberfroid MB (1991). Dietary modulation of experimental neoplastic development: role of fat and fiber content and calorie intake. Mutat. Res. 259: 351-362.

Roberfroid MB (2005). Introducing inulin-type fructans. Br. J. Nutr. 93 (Suppl 1): S13-S25.

Rodrigues MA, Silva LA, Salvadori DM, De Camargo JL, et al. (2002). Aberrant crypt foci and colon cancer: comparison between a short- and medium-term bioassay for colon carcinogenesis using dimethylhydrazine in Wistar rats. Braz J. Med. Biol. Res. 35: 351-355.

Sang S, Ju J, Lambert JD, Lin Y, et al. (2006). Wheat bran oil and its fractions inhibit human colon cancer cell growth and intestinal tumorigenesis in Apc(min/+) mice. J. Agric. Food Chem. 54: 9792-9797.

Shamsuddin AM, Vucenik I and Cole KE (1997). IP6: a novel anti-cancer agent. Life Sci. 61: 343-354.

Tian Y and Song Y (2006). Effects of inositol hexaphosphate on proliferation of HT-29 human colon carcinoma cell line. World J. Gastroenterol. 12: 4137-4142.

Tice RR, Agurell E, Anderson D, Burlinson B, et al. (2000). Single cell gel/comet assay: guidelines for in vitro and in vivo 
genetic toxicology testing. Environ. Mol. Mutagen. 35: 206-221.

Topping DL and Clifton PM (2001). Short-chain fatty acids and human colonic function: roles of resistant starch and nonstarch polysaccharides. Physiol. Rev. 81: 1031-1064.

Vucenik I and Shamsuddin AM (2003). Cancer inhibition by inositol hexaphosphate (IP6) and inositol: from laboratory to clinic. J. Nutr. 133: 3778S-3784S.

Watanabe K, Reddy BS, Weisburger JH and Kritchevsky D (1979). Effect of dietary alfalfa, pectin, and wheat bran on azoxymethane-or methylnitrosourea-induced colon carcinogenesis in F344 rats. J. Natl. Cancer Inst. 63: 141-145.

Wilson RB, Hutcheson DP and Wideman L (1977). Dimethylhydrazine-induced colon tumors in rats fed diets containing beef fat or corn oil with and without wheat bran. Am. J. Clin. Nutr. 30: 176-181. 